\title{
Instrument mix or instrument mess? The administrative complexity of the EU legislative package for climate change
}

Citation for published version (APA):

Peeters, M. G. W. M. (2014). Instrument mix or instrument mess? The administrative complexity of the EU legislative package for climate change. In M. G. W. M. Peeters, \& R. Uylenburg (Eds.), EU environmental legislation. Legal perspectives on regulatory strategies (pp. 173-192). Edward Elgar Publishing. New Horizons in Environmental and Energy Law series https://doi.org/10.4337/9781781954775.00016

Document status and date:

Published: 01/01/2014

DOI:

10.4337/9781781954775.00016

Document Version:

Other version

Document license:

Other

Please check the document version of this publication:

- A submitted manuscript is the version of the article upon submission and before peer-review. There can be important differences between the submitted version and the official published version of record.

People interested in the research are advised to contact the author for the final version of the publication, or visit the DOI to the publisher's website.

- The final author version and the galley proof are versions of the publication after peer review.

- The final published version features the final layout of the paper including the volume, issue and page numbers.

Link to publication

\footnotetext{
General rights rights.

- You may freely distribute the URL identifying the publication in the public portal. please follow below link for the End User Agreement:

www.umlib.nl/taverne-license

Take down policy

If you believe that this document breaches copyright please contact us at:

repository@maastrichtuniversity.nl

providing details and we will investigate your claim.
}

Copyright and moral rights for the publications made accessible in the public portal are retained by the authors and/or other copyright owners and it is a condition of accessing publications that users recognise and abide by the legal requirements associated with these

- Users may download and print one copy of any publication from the public portal for the purpose of private study or research.

- You may not further distribute the material or use it for any profit-making activity or commercial gain

If the publication is distributed under the terms of Article $25 \mathrm{fa}$ of the Dutch Copyright Act, indicated by the "Taverne" license above, 


\title{
EU environmental legislation:
}

legal perspectives on regulatory strategies

Chapter:

Instrument mix or mess? The administrative

complexity of the EU legislative package for

climate change

\author{
Marjan Peeters \\ (final draft before editing)
}

Published in:

Marjan Peeters, Rosa Uylenburg: EU environmental legislation: legal perspectives on regulatory strategies, Edward Elgar, Cheltenham, UK 2014, p. $173-192$

See for the published book: http://www.e-elgar.com/shop/eu-environmental$\underline{\text { legislation }}$ 
Instrument mix or instrument mess? ${ }^{1}$

The administrative complexity of the EU legislative package for climate change

Marjan Peeters

1. Aim of this contribution

In the course of combating climate change, the EU has adopted a vast legislative package aiming at the reduction of greenhouse gases with $20 \%$ in 2020 compared to the emissions from 1990. Part of this package is the EU wide emissions trading scheme. The emissions trading instrument covers only $50 \%$ of the greenhouse gases in the EU and is only one out of many legislative measures that have been adopted by the EU. ${ }^{2}$ The current legislative approach of the EU in the field of climate change contains measures for (1) emission reductions, (2) renewable energies and (3) energy efficiency. Based on these three pillars, the EU pursues a "triple 20" approach. This political choice entails the

\footnotetext{
${ }^{1}$ This title is inspired by Sorell and Sijm (2003), they state that "a policy mix may easily become a policy mess" (p 434). This contribution has been finalised in January 2013.

${ }^{2}$ European Commission (2013) p 4.
} 
following goals for 2020: 20\% greenhouse gas emission reduction, $20 \%$ renewable energy, and $20 \%$ energy saving. ${ }^{3}$ In order to reach these policy targets, a range of regulatory instruments has been established, like inter alia emissions trading, taxation, permitting, voluntary agreements, liability arrangements (for carbon capture and storage), energy labelling, eco design requirements, fuel quality standards. Next to that, support mechanisms for inter alia promoting renewable energy have been established at the EU and member state level.

The whole legislative package that supports EU climate policy is so vast and diverse that it has become an enormous challenge to master a good understanding of the specific provisions of each legislative measure and related potential legal conflicts. For instance, both for EU emissions trading and for the EU renewable energy approach many legal problems can be discussed, like the compatibility of the emissions trading instrument with the principle of equal treatment ${ }^{4}$ and the question which minimum requirements apply for administrative procedures for renewable energy activities. ${ }^{5}$ In order to get a good understanding of the workability and consequences of the package such examinations of specific legislative provisions are needed, and here a lot of work waits for the legal community. In addition to discussing separate legislative provisions, attention is needed to the whole package as such, by examining how the different

\footnotetext{
${ }^{3}$ This contribution doesn't review the justification of the triple 20 approach, and takes these political goals as a starting point.

${ }^{4}$ Epiney (2012), Peeters (2011).

${ }^{5}$ Article 13 of directive 2009/28, see case C-2/10 [21 July 2011] (Azienda Agro-Zootecnica Franchini Sari, Eolica di Atlamura Srl v. Regione Puglia).
} 
regulatory approaches of the EU legislative climate package interact. What is for instance the relationship between on the one hand the legislative approach for the reduction of greenhouse gas emissions and on the other hand the regulatory approach towards the promotion of renewable energies? This contribution aims to start a discussion in the legal literature about the EU regulatory package as a whole, discussing the instrument mix and its complexity. The embedded complexity leads to challenges for governments that have to apply the laws. This important task is primarily allocated to member states. The contribution will point at the need to pay attention to the comprehensiveness of the regulatory approach towards climate change and discusses possibilities for simplification. The chapter is structured as follows: section 2 starts with a discussion of the current package thereby stipulating the risk of future non-compliance by member states, after which some interferences between regulatory approaches will be discussed in section 3 . Section 4 discusses the potential simplification of the package, thereby pointing at the principle of equal treatment and the proportionality principle, after which section 5 will conclude.

2. The regulatory instrument package in EU climate law

2.1 A target based approach with a huge compliance challenge

Developing effective regulatory approaches for the problem of climate change is obviously an immense challenge. The EU has chosen to set targets (the "triple 20" targets explained in section 1) and consequently, secondary legislation has been adopted in order 
to achieve those targets. ${ }^{6}$ Part of this legislation translates the EU triple 20 targets to specific legally binding targets for member states. This is the case with the Effort sharing decision (Decision 406/2009/EC) which obliges member states to achieve greenhouse gas emission reduction targets in 2020 concerning sources that are not covered by the EU emissions trading scheme (the EU ETS). Secondly, the Renewable energy directive (2009/28/EC) imposes renewable energy targets on member states, also to be complied with in 2020. The EU ETS applicable from 2013 onwards doesn't use national targets and is based on an EU-wide cap which represents the maximum amount of emissions that may be caused by EU ETS industries. This cap contributes to the EU wide target of $20 \%$ greenhouse gas emissions reduction in 2020. In sum, the EU ETS directive, the Renewable energy directive and the Effort sharing decision start from targets to be reached. The EU ETS has an EU-wide target while the Renewable energy directive and the Effort sharing decision rest on member state targets. This target-approach assumes that sufficient measures will be taken in order to reach compliance: a lot of steering needs to be done in order to reach compliance. The field of environmental law is however very much known for non-compliance behavior, and particularly it are often member states that do not comply with the set obligations. The environmental field was one of the four most infringement prone areas in 2011, and almost half of the Article 260(2) TFEU infringement procedures in 2011 related to the environment. ${ }^{7}$ The origin of the problem of non-compliance by member states is often that member states fail to steer private actors in their national systems to less polluting behavior. This well-known problem of

\footnotetext{
${ }^{6}$ For an overview of adopted measures, see Jans, Vedder (2012) p 431-445.

${ }^{7}$ European Commission (2012-2) p $10-11$.
} 
non-compliance with EU environmental law has thus far got little attention in the legal literature concerning the new legislative measures for climate change. Given the fact that the package of climate law is broad and diverse, entailing the need for a behavioral change in a rather short time frame in order to cause less carbon emissions, the review of legal problems that governmental authorities might meet in executing the adopted EU secondary legislation is an urgent matter. In the field of the EU ETS, this review should at least concentrate on the monitoring and enforcement of the legal framework for greenhouse gas emissions trading by member states, while in the field of the Effort sharing decision - with its emission reduction targets for each member state to be complied with in 2020 - the review of the national means for steering the non EU ETS sources deserves examination. ${ }^{8}$ In the field of the renewable energy directive, also national choices and related legal measures to enable compliance with the renewable energy consumption target for 2020 forms the focal point.

The overview above is however not a complete one. In addition to the secondary legislation aiming at the reduction of greenhouse gas emissions and the promotion of renewable energy, a new directive on energy efficiency measures has been adopted in 2012 (Directive 2012/27/EU). This measure intends to contribute to the third " $20 \%$ target" concerning the reduction of energy consumption in the EU to be realized through energy efficiency and energy saving measures. The directive, based on art. 194(2) TFEU, establishes indicative national energy efficiency targets for 2020 (art. 1 and art. 3). The member states may decide themselves what their specific target will be taking into

\footnotetext{
${ }^{8}$ Peeters, Stallworthy, De Cendra de Larragàn (2012).
} 
account criteria provided by the directive. Next to that, the directive contains a range of regulatory measures to be implemented by member states. thereby offering a lot of flexibility to member states, like the option to exclude EU ETS industries from the calculation needed for the obligatory energy efficiency obligation scheme (art. 7(2)(b). It is even possible for member states to choose for alternative policy measures instead of the energy efficiency obligation scheme, provided that it will lead to the same amount of new energy savings (art. 7(9)). Moreover, in addition to the energy efficiency obligation scheme the directive imposes inter alia the following measures: several measures for improving the energy-efficiency of buildings (art. 4 and 5)), the obligation for central governments to purchase only products, services and buildings with high-energy efficiency performance (art. 6), energy audits to be made available for customers including small or medium enterprises, including the possibility of financial aid (art. 8), an obligatory energy audit for enterprises not being qualified as small or medium enterprises (art. 8(2)), the need to provide final customers with individual meters that accurately reflects the energy consumption (art. 9), assessment and promotion of cogeneration (art. 14), energy efficiency measures for the energy infrastructure (art. 15) and the improvement of the energy service market (art.18). In sum, the Energy efficiency directive entails a lot of different measures that request a huge implementation effort from member states and, of course, also efforts from private actors that will be addressed through these national measures. Particularly the question what the potential cost effects are for those private actors might lead to sensitive political discussions in the national implementation phase of the directive. In addition, also the other legislative measures of the EU climate package will of course bring along a cost for society, which will become 
visible during the execution of the package within member states. The "the devil is in the detail" in this context can be rephrased as "the devil is in the implementation phase".

2.2 Many implementation challenges within the regulatory instrument package

The package of EU climate law consists of a puzzling amount of different regulatory approaches that ask for member states`action. Above, a range of measures being part of the new Energy efficiency directive has been mentioned. Some striking other examples of regulatory provisions that ask for important implementation efforts are:

a. The market based instrument of emissions trading. This instrument can be designed in very different ways, and it yet has to be examined whether the EU chose the best one. ${ }^{9}$ The fact that the EU already after five years after the adoption of the EU ETS directive chose for a large reform illustrates this design challenge. ${ }^{10}$ After a deep reform of the EU ETS with directive 2009/29/EU, a new amendment is already foreseen in view of building a tighter price control on the EU greenhouse gas allowances. ${ }^{11}$ The reform with directive 2009/29/EU took away the competence for member states to decide on the national allocation of allowances, but a very important task remains with them which is the monitoring and enforcement of the scheme. Particularly this aspect of the EU ETS

\footnotetext{
${ }^{9}$ Peeters, Weishaar (2009).

${ }^{10}$ European Commission (2008).

${ }^{11}$ European Commission (2012-1) announcing the proposal for an amendment of the EU ETS directive and a proposal for an amendment of the auction regulation.
} 
has thus far got little attention in legal literature. ${ }^{12}$ One may fear that potential noncompliance by industries, particularly in member states with short falling governmental capacities and member states that suffer from corruption will not be detected. In other words: legal problems (non-compliance by industries) may be the case, but will it be detected and be addressed adequately? Here lays a crucial implementation task for member states that should get more attention from legal literature. Are the current monitoring and enforcement competences adequate enough, and is there enough capacity to execute them? How do member states deal with the specific figure of the private verifier, who is to be hired by the emitter in order to verify its emission report? Are there sufficient control mechanisms in place to check these verifiers, and to impose adequate sanctions in case of malfunctioning or even worse?

b. Support mechanisms for renewable energy, to be established by member states. ${ }^{13}$ Contrary to the new centralized model for emissions trading introduced with directive 2009/29/EU, the renewable energy approach by the EU can be characterized by a decentralized approach where member states have to decide on national policies for compliance with national renewable energy targets. In this vein, the establishment of national support mechanisms plays an important role. Member states can choose among a range of support mechanisms, like investment aid, tax exemptions or reductions, the establishment of renewable energy obligation support schemes including green certificates, and direct price support schemes including feed-in tariffs and premium

\footnotetext{
${ }^{12}$ Epiney (2012); Peeters (2006).

${ }^{13}$ Article 3 of directive 2009/29. Next to that, member states can engage into cooperation with other member states in order to achieve the targets.
} 
payments. In sum, the regulatory approach towards the promotion of renewable energy largely differentiates in the EU, by means of different support mechanisms. Such differentiation can be fruitful in order to have a learning process about the design and effectiveness, including its related legal problems, of different support mechanisms. It is however no easy matter to design, on the national level, an adequate support scheme. ${ }^{14}$ Case law learns that particularly the stability of the support mechanism is a concern, since governments seem willing to amend established approaches. ${ }^{15}$

c. Administrative procedures for renewable energy projects Member states have to conduct the immense task of the transformation of the energy production in society from a fossil fuels based one to a carbon low one. The Renewable energy directive brings along in article 13 a surprisingly far going harmonization of the administrative procedures that member states apply when they make decisions regarding to renewable energy projects like windmills, hydro-energy installations and biomass facilities. The aim of the article is to make the decision-making for these projects efficient in order to contribute to the achievement of the renewable energy targets. However, when executing these administrative procedures member states have to deal with the resistance against projects such as windmill parks and biomass facilities. The decision-making on renewable energy projects can easily lead to legal problems, as already has occurred before the CJEU and the ECtHR. ${ }^{16}$ Resistance can stem from private concerns,

\footnotetext{
${ }^{14}$ Banet (2012).

${ }^{15}$ See for instance C-201/08, [10 september 2009] Plantanol GmbH \& Co. KG - Hauptzollamt Darmstadt.

${ }^{16}$ CJEU: C-2/10 [21 July 2011] (Azienda Agro-Zootecnica Franchini Sari, Eolica di Atlamura Srl v.

Regione Puglia), and ECtHR: Fägerskiöld v. Sweden (25 march 2008), application number 37664/04.
} 
particularly the protection of the value of property, but can also stem from public health and nature concerns. Article 13 does not refer to the Aarhus Convention but it is obvious that member states, in executing the administrative procedures for renewable energy projects have to comply with the procedural rights from this convention. ${ }^{17}$

d. Substantive standards for biofuel: the Renewable energy directive imposes on member states the duty that in $202010 \%$ of the energy consumed in transport has to consist of renewable energy. In view of this, the EU has formulated a set of substantive criteria that should ensure the sustainability of the biofuel used for compliance with this member state target for transport. The EU could not yet succeed in adopting sustainability requirements for biomass: the criteria only apply for biofuels in transport. Moreover, these criteria only apply for measuring the commitment of the member state with the target of $10 \%$ renewable energy in transport. This means that biofuels that do not meet the sustainable criteria of the directive are not forbidden by the directive; it only means that these biofuel cannot be counted by the member states for the achievement of the $10 \%$ target. The specific formulation of the substantive criteria and its impact on third countries is a very sensitive matter. Moreover, also here a compliance concern can be seen: how will be checked that the biofuels counted towards the targets actually met the set sustainability criteria?

e. A legal framework for carbon capture and storage, with in its core permit and liability provisions to be implemented by member states. As such, the choice whether or not to allow carbon storage on the national territory is free: member states may choose not to enable this new technology. If a member states chooses to do so, legal action by citizens

\footnotetext{
${ }^{17}$ See for the authorisation of energy generation activities also article 7 of directive 2009/72/EC.
} 
and NGO's can be easily foreseen, as carbon storage is often perceived as a sensitive matter not being the right choice for the transition to a carbon free society. 9

\subsection{Additional relevant EU laws}

It would be wrong to assume that EU climate law can only be understood by considering the specific secondary legislation established for the reduction of greenhouse gases, the promotion of renewable energy, and the achievement of energy efficiency. Some examples of additional relevant secondary legislation are:

- the Nature conservation legislation (Habitat and Birds directives) ${ }^{18}$ For example the establishment of windmills and hydro-energy legislation can impinge upon conditions stemming from those directives.

- the Environmental Liability Directive. ${ }^{19}$ Particularly in the case of carbon capture and storage, the provisions of this directive need to be taken into account as well. But the relevance of the directive has also to be examined in case the functioning of renewable energy works might cause damage to protected species.

- Air Quality directives: particularly for the establishment of biomass installations, the traditional air quality concerns need to be taken into account. Biomass installations may contribute to emissions of nitrogen dioxide and particulate matter, which is covered by directive 2008/50/EC on ambient air quality. ${ }^{20}$ Quite some member states face difficulties

\footnotetext{
${ }^{18}$ Directive 92/43/EEC; Directive 2009/147/EC.

${ }^{19}$ Directive 2004/35/EC.

${ }^{20}$ See the information of http://www.environmental-protection.org.uk/biomass/
} 
with compliance with the imposed air quality standards, including nitrogen dioxide and particulate matter. ${ }^{21}$ Moreover, there may appear remarkable interferences between on the one hand the use of EU emissions trading and on the other hand the reduction of traditional air pollutants like NOx. A study has shown that the purchase of rather cheap emissions rights outside the EU by national governments may lead to additional costs for the reduction of NOx-emissions. ${ }^{22}$

- the Industrial Emissions Directive: Many EU ETS sources are also covered by the IED directive. ${ }^{23}$ This directive gives member states the opportunity to include energy efficiency conditions in the permit. ${ }^{24}$ Moreover, the preamble of the directive mentions the possibility of more stringent measures to be taken by member states, "for example greenhouse gas emissions requirements". ${ }^{25} \mathrm{Next}$ to that, the European Commission is examining to propose new legislation in order to include smaller combustion plants of less than 50 megawatts that have not yet been included in the Industrial Emissions Directive. This approach could lead to further encouragement to switch to renewable energies, particularly biofuel and biomass. ${ }^{26}$ Of course, the permit systems and the approach to small combustion installations have to be executed by the member states.

\footnotetext{
${ }^{21} \mathrm{See}$ http://ec.europa.eu/environment/air/quality/legislation/time extensions.htm (accessed 22 July 2012).

${ }^{22}$ National Institute for Public Health and the Environment (2004).

${ }^{23}$ IED directive: Directive 2010/75/EU of the European Parliament and of the Council of 24 November 2010 on industrial emissions (integrated pollution prevention and control).

${ }^{24}$ Art. 9(2) IED directive.

${ }^{25}$ See preamble 10 IE directive. See for a discussion Squintani a.o., (2012).

${ }^{26}$ ENDS Europe Daily, EC ponders action on smaller combustion plants, Monday 23 July 2012.
} 
In addition, EU legislation that specifically sees on fossil fuel activities, like offshore drilling, is of course also influential for choices made in view of the transition to a low carbon society. It falls outside this contribution to provide an overview of these relevant secondary rules, and the required implementation effort by member states like authorization procedures and monitoring tasks. As an example the development of a new secondary law for offshore drilling can be mentioned: this concerns a proposal from the European Commission for a regulation regarding the exploration and production activities for oil and gas installations. ${ }^{27}$ Ultimately, it is the whole package of climate laws and also fossil fuel related laws that determines what the conditions are for the continuation or termination of greenhouse gas emitting activities.

\subsection{New developments}

A full overview of EU climate law measures, related measures, and fossil fuel legislation is even not yet enough, since new developments are looming. On the international level decisions have been adopted to regulate two new greenhouse gas pollutants. First, within the framework of the Convention on Long-range Transboundary Air Pollution (LRTAP) black soot has been explicitly added (as a component to particulate matter) in 2012 to the 1999 Gothenburg Protocol to Abate Acidification, Eutrophication and Ground-level

Ozone. ${ }^{28}$ This obliges the EU and its member states to develop policies in order to

\footnotetext{
${ }^{27}$ European Commission (2011).

${ }^{28}$ See http://www.unece.org/index.php?id=29858, accessed 22 July 2012.
} 
comply with the set emission reduction commitment for 2020. Secondly, under the umbrella of the UNFCCC, particularly the Kyoto Protocol, it is decided to include a seventh greenhouse gas to Annex A of the Kyoto Protocol, which is Nitrogen trifluoride $\left(\mathrm{NF}_{3}\right) .{ }^{29}$ Next to these extensions of the international legal framework for greenhouse gas pollutants, there is also discussion of how to move forward with the international regulatory approach, which can have consequences for the EU internal climate law approach. Particularly the development of a new international market-based mechanism currently in discussion under the UNFCCC may lead to new approaches with emissions trading by and within the EU. Moreover, as soon as on the international level an agreement will be reached about more ambitious climate protection, the EU has to amend its $20 \%$ greenhouse gas emission reduction target to for instance $30 \%$ in 2020 (or any other new target) which of course needs to be translated into the internal EU climate law package.

One very different development in the course of executing the full climate package can be the potential energy price increase which might be caused by the fact that renewable energies and energy efficiency measures will become expensive. Here, the question is whether society (represented by politicians) will indeed be ready to accept this price increase. With regard to the price effects of the EU ETS, the member states have certain powers to deal with it: the EU ETS contains a provision to mitigate the cost of energy price increase for energy intensive industries, meaning that member states may provide

\footnotetext{
${ }^{29}$ UNFCCC, Decision 1/CMP.7 adopted in 2011, see UNFCCC document number FCCC/KP/CMP/2011/10/Add.1 (15 March 2012).
} 
support to such industries as long as it stays within state aid guidelines. ${ }^{30}$ One can hence see that through the 'backdoor' relief can be given to a specific group of private actors (the energy intensive industries) covered by the EU ETS instrument. For the environmental effectiveness, this should not be a problem: the amount of issued allowances stays the same.

2.5 Conclusion: a complex package with impressive execution challenges

The above non-exhaustive discussion has shown that the EU has chosen to establish a legislative package consisting of different regulatory approaches in order to pursue its triple 20 approach. The package asks for a lot of administrative decision-making, not only on the EU level (like regarding the assessment of support measures in view of state aid but also legal provisions for the allocation of allowances) but also to a very large extent on the member state level. It is in the implementation phase that legal problems and case law can be expected. In the legal literature it has been argued that "It is surprising that so many efforts (as human work and financial means are concerned) have been undertaken in order to introduce a new system whose effectiveness and efficiency is at least uncertain". ${ }^{31}$ Indeed, the implementation of the EU ETS asks for a lot of complex

\footnotetext{
${ }^{30}$ See article 10a(6) of the EU ETS directive (consolidated version, published at http://eurlex.europa.eu/LexUriServ/LexUriServ.do?uri=CELEX:02003L0087-20090625:EN:NOT (accessed 20-082012).

${ }^{31}$ Epiney (2012).
} 
administrative decision-making with a related administrative burden. However, the full burden of EU climate law can only be understood after an examination of the whole package, and hence the issue of complex administrative decision-making and related administrative burden is much higher when one indeed considers the whole package: particularly the Renewable energy directive but also the Effort sharing decision and the Energy efficiency directive ask for a lot of governmental work on member state level. One may fear that the complexity of the chosen package and the related administrative burden will threaten the ultimate effectiveness. Before discussing the potential for a simpler regulatory choice in section 4 , the next section discusses some potential interferences between the several instruments of the package.

3. Interactions in view of the EU package

3.1 National measures and the waterbed effect

The triple 20 approach as pursued by the EU is according to the IPCC projections not ambitious enough to deal effectively with climate change: developed countries should aim at 25 to $40 \%$ emission reductions in $2020 .^{32}$ The fact that the EU target is not the most ambitious one has led to national considerations to pursue a more stringent approach. This has specifically been done in the United Kingdom, where the `Climate Change Act 2008' has been adopted that in two respects sets a more ambitious legal framework

${ }^{32}$ See IPCC (2007). 
- it includes a long term commitment of $80 \%$ reduction in 2050 ;

- it includes an emission reduction effort of $34 \%$ for 2020.

However, as will be shown below, there is a remarkable effect hidden into the EU legislative package for climate change, which is called the waterbed effect. ${ }^{33}$ It means that the total amount of emissions in the EU will not necessarily decrease if unilateral national action is taken. This effect can occur both under the EU ETS and the Effort Sharing Decision. How does this work? The following example serves as an illustration: Suppose a member state adopts an ambitious national target, which means that additional unilateral measures have to be imposed on emitting sources. We can suppose that the government addresses EU ETS sources with energy efficiency measures, as is allowed according to Article 26 of the EU ETS directive. This means that these sources have to reduce emissions, which consequently means that they will buy less allowances on the market or, if they got allowances for free, may sell their allowances on the market. Because of the EU wide cap, the amount of emissions in the EU stays the same. ${ }^{34}$ The only effect is that in one member state (where ambitious energy efficiency measures are imposed) the greenhouse gas emissions caused by the specific sector will drop, while

\footnotetext{
33 The Netherlands Environmental Assessment Agency framed the problem as the 'waterbed effect', Netherlands Environmental Assessment Agency (2008). See also Scott (2011) (p 27) and Peeters (2008). (p 36-37).

34 This effect may also occur in case member states consider to use the as such not yet well understood option provided by the IED directive to impose further going emission reductions, see Squintani a.o (2012).
} 
other sources in the EU may buy the allowances. Because of the decrease of demand (the addressed sources do not need the allowances anymore) the price of the allowances might decrease. Hence, unilateral measures in order to pursue an ambitious climate policy in line with the IPCC would lead - within the EU legal framework for emissions trading to cheaper allowances for other EU ETS sources outside the country.

The same effect will occur when a member state allows for carbon capture and storage. With carbon capture and storage, particularly onshore, citizens living in a certain area will be burdened with the fact that the storage activity takes place. This negative effect is of a local nature, while the activity aims to contribute to the solution of the global problem of climate change. However, the total amount of emissions in the EU stays the same: the industries that opt for carbon capture need less allowances (the carbon dioxide will not be emitted into the air) which means that those allowances can be bought by others. Particularly if the carbon capture and storage will be supported with governmental funding, it means that indirectly this funding will contribute to cheaper allowances for EU ETS sources.

Also the Effort Sharing Decision may cause waterbed effect situations. This decision enables member states to pursue a more ambitious climate policy for non EU ETS sources, meaning that the surplus of emission reductions (the over achievement) may be sold to other member states. It means that a national policy on for instance agricultural sources that asks more than is needed in order to comply with the minimum target imposed by the EU can lead to governmental income by selling the surplus amount. The 
total amount of emissions in the EU again stays the same, as the member states who get the surplus may use it and consequently have to impose less ambitious standards on their EU ETS sources. ${ }^{35}$

The waterbed effect can also be seen when the renewable energy directive and the EU ETS directive will be considered together. ${ }^{36}$ If a national government subsidizes the establishment of renewable energies (which could go further than the imposed targets for 2020), the demand for fossil fuels will become less. The lower demand can lead to a price decrease of the allowances, which means that for instance chemical industries or other sources covered by the EU ETS will be able to buy cheaper allowances. A related effect is that there will be less incentive coming from the EU ETS to technological innovations. This example shows that the effects of the renewable energy directive and the EU ETS cannot be seen in isolation: a higher effort for renewable energies (and also energy efficiency and energy saving) leading to a decrease of the generation or use of fossil fuel energy might lead to cheaper allowances for EU ETS industries. The legal framework for the EU ETS hardly contains price management options which means that it is hard to fine tune the effects of (needed) national more ambitious policies with the EU ETS allowance market.

\footnotetext{
${ }^{35}$ Peeters and Stallworthy (2012).

${ }^{36}$ Sorell, Sijm (2003) already noted the risk that different policy instruments might interfere with one another and undermine the objectives and credibility of each other.
} 
In conclusion, the waterbed effect might deter member states from imposing additional measures on industries in their jurisdictions covered by the EU ETS because they cannot capture any direct environmental benefits when the emissions are merely displaced to another source. Alternatively, it might form an argument for member states to plea for a more ambitious, common climate policy on the EU level.

\subsection{Conclusion}

Economic literature argues that a portfolio of different policies can reduce emissions at a lower social cost than any single policy. ${ }^{37}$ It is however no easy matter to design an adequate instrument mix that will enable the policy goals in a low-cost way, not only for the emitters but also for the governments that have to administer the laws. The discussion in this section has shown that the complex package of EU climate law brings along complex decision-making for member states. Moreover, one can see that the package is not very stimulating for member states to pursue more ambitious policies, because of the waterbed effect and related interactions between the several measures.

\section{Considering simplification}

\footnotetext{
${ }^{37}$ Fankhauser a.o., (2010). Sorell and Sijm (2003) argued that, once the ETS is in place, the justification for maintaining other instruments must rely upon another rationale than the contribution of the instrument to overall emission reductions (p. 426).
} 
Particularly in the field of EU climate law one may fear that the law has already become so complex that it cannot be fully understood and implemented and complied with in practice. This leads to the question whether the regulatory approach can be simplified. For such simplification the establishment of fewer instruments can be considered. ${ }^{38}$ In fact, literature has already pointed at the idea to establish only one carbon market to bring greenhouse gas emissions down. This proposal from the American scholar Jonathan B. Wiener entails that all greenhouse gases, sectors and sink possibilities (this concerns the storage of carbon in for instance forests) should be covered by one carbon market. ${ }^{39}$ In his analysis, he points at the negative effects of fragmentation of laws, which can "yield conflicting policies that frustrate each other, or duplicative policies that waste effort". The inclusiveness of the approach is very much motivated by the need to prevent leakage from a regulated sector to another, undermining the environmental efficacy of the regulatory approach. From a legal point of view, one could add that the principle of equal treatment indicates towards an inclusive approach. It is the Court of Justice of the EU that has put all greenhouse gas emitters on the same footing: they are all to be seen as polluters. ${ }^{40}$ This does not mean that differential approaches can be applied by the EU legislator but such differentiation needs to be based

\footnotetext{
${ }^{38}$ One could also consider establishing less policy targets, for instance an ambitious greenhouse gas reduction target that would bring along renewable energy and energy efficiency measures.

${ }^{39}$ Wiener (2008). He also discusses the possibility of a tax, but the preference goes to a cap and trade emissions trading system, also because of its attractiveness for the international regulatory approach (p. 22). See also Weisbach (2012) discussing an upstream pricing system (cap and trade), which would be simpler to administer.

${ }^{40}$ Peeters (2009).
} 
on objective and transparent criteria. Hence, the necessity to have an inclusive approach to all emitters does not necessarily mean that all emitters will be treated in the same way: based on objective reasons some industries may have higher burdens than others. One could even imagine that a legislator would differentiate among necessary and luxury emissions, meaning that the latter would deserve tougher obligations. Furthermore, the idea of Wiener to encompass all sources into a carbon market evidently requires a comprehensive monitoring and enforcement system. He states that most likely relatively high costs of measuring emissions and sink sequestration in some sectors will likely be dwarfed by the environmental benefits and social cost savings of encompassing all sectors. $^{41}$

The starting point is that all emitters should be included in the regulatory framework. One can see that this is to quite a large extent the case in the EU, as the Effort Sharing Decision includes the non EU ETS sources, while the EU ETS covers the others. Consequently, the major part of emitters in the EU is covered by the EU regulatory package, albeit that they are covered by different regulatory approaches. One sector that is yet excluded is international shipping. This illustrates there is differential treatment by the EU between international aviation emissions and international shipping emissions: the first are included into the EU ETS, the latter not. Whether this brings along a negative competitive position for air operators, because of the fact that goods will be transported by ships instead by planes, is something to be further explored. As long as the carbon price of the EU ETS stays rather low, such effect can hardly be expected. If however the EU turns to more ambitious policies, particularly for the aviation sector, while not

\footnotetext{
${ }^{41}$ Wiener (2008) p. 22.
} 
imposing duties on the shipping sector, the effects may become more intense which ultimately may influence the competitive positions. This would entail a leakage effect, meaning that if transport of products will move to shipping the transport will continue with fossil fuel emissions.

The idea of one truly EU wide greenhouse gas emissions trading scheme might serve as a model for the future, and it is worthwhile to review the potential political and legal problems. If it is indeed true that all actors that emit greenhouse gases can be qualified as polluters, what is then the justification to treat them through different instruments? How could a potential EU-wide emissions trading scheme look like? And how could the EU carbon market contribute to side-goals like the energy security of the EU? It would be worthwhile to start a research project based on the assumption that all emitters are put under the same instrument, and that exceptions should rest on a strong justification. Difficult questions have to be answered, like which differential treatment will be necessary within the carbon market, like is now the case with the EU ETS where differentiation is made among fossil fuel powered energy installations, that have to buy the allowances from the auction or the secondary market, and for instance the chemical sector, that will get the allowances partially for free. In principle, such differential treatment should be an exception, based on a clear justification. 
Nevertheless, other models are possible too, particularly if one would consider to develop a regulatory approach based on the concept of human rights. ${ }^{42}$ If we start from the assumption that every human being has an equal right to a certain amount of emissions in order to meet the needs of life like food, energy and transport, the total amount of allowable emissions (taking into account consumption) can be calculated. It can then be considered to allocate per capita allowances to citizens. It is worthwhile to explore such revolutionary but human rights based approaches, since the current legislative system is not per se the most ideal one and even seems to disconnect citizens to the EU wide climate law approach. ${ }^{43}$ Of course, in the course of studying this human rights based model, also the potential negative social problems should be addressed (like particularly the position of disabled persons and elderly people, as they most likely will need more allowances than average people).

The basic conclusion is however that the idea of one ambitious carbon market seems appealing for reasons of simplicity and, in this vein, the reduction of implementation efforts. The legal framework for this carbon market should be ambitious enough to ensure

\footnotetext{
${ }^{42}$ See for instance Ekardt, Von Bredow (2012) pointing at the per capita approach (p 54-56): “Our approach consists of a steadily decreasing and rigid global cap on greenhouse decreasing and rigid global cap on greenhouse gas emissions in conjunction with an emissions trading system between all countries, based on an initial allocation of emission certificates according gas emissions in conjunction with an emissions trading system between all countries, based on an initial allocation of emission certificates according to the principal of world-wide equal emissions rights per capita, starting with approximately 5 tons of CO2 per capita and arriving at 1 ton per capita in 2050 ”.

${ }^{43}$ Peeters (2008).
} 
the reduction of emissions that according to scientists is needed. How the legal framework for such a market can be developed is something to be further explored. One important point of attention will be whether - after having established an ambitious and inclusive carbon market - accompanying renewable energy and energy efficiency legislation would be still needed. Perhaps the multitude of currently established rules, and its related complexity, will naturally lead to a strong call for simplification which in principle most likely would mean a further expansion of the EU ETS. Interestingly, the question of equal treatment of sources can then be explored discussed within the scope of that instrument. It is obviously more doable to discuss a legal value like the equal treatment of sources within one single instrument than in a package consisting of different regulatory approaches. 


\section{Conclusion}

EU policy for climate change is based on three different targets. An impressive range of directives and other EU-secondary laws have been adopted in order to reach these targets. This regulatory package has become very complex and poses the administration particularly the member states who have to make the package work - for a huge execution challenge. The establishment of many laws that ask for extensive governmental action in order to conduct inter alia permit systems, support mechanisms, and monitoring and enforcement may entail the risk that difficulties emerge with the execution of the laws. Moreover, potential interferences between the regulatory instruments may bring along negative effects, like higher costs for emitters compared to a single instrument, and disincentives for unilateral member state action. Was it really necessary to adopt a range of complicated legislative instruments in order to achieve the goals of climate protection? Or is the amount of measures showing the weakness of the politicians, meaning that if one instrument has not been designed ambitious enough, additional instruments have to be imposed? It would be interesting to examine whether a more inclusive approach can be developed in the EU by means of an ambitious carbon market that includes all carbon emitters. The benefit would be that the amount of instruments can be reduced, and that the administrative execution of climate law will be simplified, and core tasks, like monitoring and enforcement, can perhaps be better executed. Whether these assumptions are true, deserves further research. 


\section{BIBLIOGRAPHY}

Banet, C., Tradable green certificates under EU law - The influence of EU law on national support schemes for renewable electricity generation, $\mathrm{PhD}$ thesis University of Oslo, 20 august 2012 (forthcoming Kluwer Law International)

Ekardt, Felix, Hartwig von Bredow (2012), Extended Emissions Trading Versus Sustainability Criteria: Managing the Ecological and Social Ambivalences of Bioenergy, Renewable Energy Law and Policy Review (1) 49-64.

Epiney, A. (2012), Climate Protection Law in the European Union - Emergence of a New Regulatory System, Journal for European Environmental \& Planning Law, 9(1), 533.

European Commission (2008), Proposal for a directive of the European Parliament and of the Council amending Directive 2003/87/EC so as to improve and extend the EU greenhouse gas emission allowance trading system, Brussels, COM 2008(16) final (adopted on 23.1.2008).

European Commission (2011), Proposal for a Regulation on safety of offshore oil and gas prospection, exploration and production activities, Brussels, 27.10.2011, $\operatorname{COM}(2011) 688$ final 
European Commission (2012-1), Press release "Emissions Trading: Commission

prepares for change of the timing for auctions of emission allowances", Brussels, 25 July 2012.

European Commission (2012-2), 29th annual report on monitoring the application of EU Law (2011), Brussels, 30.11.2012, COM(2012) 714 final.

European Commission (2013), Green Paper: A 2013 framework for climate and energy policies, Brussels 27.3.2013, COM(2013)169 final.

Fankhauser, S, C Hepburn, J Park (2010), Combining multiple climate policy instruments: how not to do it, Climate Change Economics 1(3), 209-225.

IPCC (2007), Fourth Assessment Report, Working Group III, chapter 13, Box 13.7, p. 776; also B. Metz, O.R. Davidson, P.R. Bosch, R. Dave, L.A. Meyer (eds.) (2007) Contribution of Working Group III to the Fourth Assessment Report of the Intergovernmental Panel on Climate Change, 2007. Also Published on http://www.ipcc.ch/publications_and_data/publications_ipcc_fourth_assessment_report_ wg3_report_mitigation_of_climate_change.htm (last visited 8 August 2013).

Jans, J.H., Vedder H.B., (2012), European Environmental Law. After Lisbon, 4th edition, Europa Law Publishing. 
National Institute for Public Health and the Environment (The Netherlands, RIVM;

W.L.M. Smeets, A. Hoen en R. van den Wijngaart) (2004), Synergie Klimaat-en NOxbeleid. Een kostenevaluatie tot 2010, rapport 500037006/2004, http://www.rivm.nl/bibliotheek/rapporten/500037006.pdf (accessed 8 August 2013).

Netherlands Environmental Assessment Agency (2008), Consequences of the European Policy Package on Climate and Energy, available at http://www.pbl.nl/en/publications/2008, accessed (8 August 4 2013).

Peeters M, (2006), Enforcement of the EU greenhouse gas emissions trading scheme, in: K. Deketelaere, M. Peeters: EU Climate Change Policy: The Challenge of New Regulatory Initiatives, Edward Elgar Publishing, 169-187.

Peeters M (2008), Legislative Choices and Legal Values: Considerations on the further design of the European Greenhouse Gas Emissions Trading Scheme from a viewpoint of democratic accountability, in: MG Faure, M Peeters (eds.), Climate Change and European Emissions Trading: Lessons for Theory and Practice, Edward Elgar Publishing, 17-52.

Peeters, M, S Weishaar (2009), Exploring Uncertainties in the EU ETS: "Learning by Doing” Continues Beyond 2012, Carbon and Climate Law Review, 1, 88-101. 
Peeters M (2011) The EU ETS and the role of the courts: Emerging contours in the case of Arcelor, Climate Law 2, 19-36.

Peeters, M, M Stallworthy and J de Cendra de Larragàn (2012) Climate Law in EU Member States, Edward Elgar Publishing.

Peeters M, M Stallworthy (2012), Legal Consequences of the Effort Sharing Decision for Member State Action, Marjan Peeters, Mark Stallworthy, Javier de Cendra (eds), Climate Law in EU member states, Edward Elgar Publishing.

Scott J (2011) 'The Multilevel Governance of Climate Change', Carbon and Climate Law Review 1/2011, 25-33.

Sorell, S, J Sijm (2003), Carbon Trading in the Policy Mix, Oxford Review of Economic Policy, 19(3) 420-437.

Squintani ., K de Graaf, M Holwerda (2012), Regulating Greenhouse Gas Emissions from EU-ETS Installations: what Room is left for the Member States?, in: Marjan Peeters, Mark Stallworthy and Javier de Cendra de Larragàn (2012) Climate Law in EU Member States, Edward Elgar Publishing.

Weisbach D (2012), Carbon Taxation in Europe: Expanding the EU Carbon Price, 24 Journal of Environmental Law 183 (2012). 
Wiener J.B. (2008), Radiative forcing: Climate Policy to Break the Logjam in Environmental Law, Duke Public Law \& Legal Theory Research Paper Series no. 225, http://scholarship.law.duke.edu/cgi/viewcontent.cgi?article=2550\&context=faculty_schol arship (accessed on 22 July 2013). 
